\title{
Deborah Uman and Sara Morrison (eds). Staging the Blazon in Early Modern English Theatre. Farnham, Surrey: Ashgate, 2013. Pp 220.
}

YOLANA WASSERSUG

Shakespeare Institute, University of Birmingham
Early Theatre 17.1 (2014), 229-232

DOI: http://dx.doi.org/10.12745/et.17.1.18

Any scholar with an interest in blazon will have encountered Nancy Vickers's writing on the use of blazons by Petrarch's early modern successors. For some thirty years, Vickers's essays have been central to the discussion of the gendered power dynamics of blazons as poetic devices which enable the determining male gaze to control the female body through verbally dismembering it. ${ }^{1}$ In Staging the Blazon in Early Modern English Theatre editors Deborah Uman and Sara Morrison seek to build on Vickers's foundational work, and they also acknowledge their indebtedness to Jonathan Sawday and Lynn Enterline. Their aim is to fill the lacunae that these scholars leave when they focus their attention on the blazon as a lyric rather than theatrical device. 'The dramatic potential of the blazon', write Uman and Morrison, 'has not yet been considered in a sustained and comprehensive manner' (6). While the stated goal of this collection of essays is to make the stage and performance central to understanding blazon, a secondary aim in the essays is to reconsider the gender dynamics of this kind of writing, making the case that on the early modern English stage it is not always true that a blasonneur is male and his objectified subject is female.

Several essays in the collection draw on new approaches to source material in order to make the staging and performance of blazon central. Lisa S. StarksEstes's essay, for instance, rethinks the often-discussed staging of Lavinia's mutilated body by considering Shakespeare's appropriation of Ovidian imagery. Starks-Estes reminds readers that an 'obvious source of erotic visual imagery in this play' (60) is Ovide Imagisé; the widely circulated illustrations of scenes from the Metamorphoses which accompanied both Latin and translated versions of the text. Shakespeare's grotesque image of Lavinia standing on stage in tableau while her uncle blazons her mutilated body allows Shakespeare to use Lavinia's body as a living illustration, and to associate Lavinia not only with Philomela but as a kind of amalgam of Ovidian figures. Other contributors to the book choose to make theatre central to their discussion by focusing on particular productions, rather than the idea of performance as a whole. Thomas P. Anderson, for instance, argues that Julie Taymor's film 
adaptation of the play interprets Lavinia as the locus of what he calls 'corporeal feminism' (122). Lisa Dickson similarly makes specific productions her focus, examining the Royal Shakespeare Company's productions of The Wars of the Roses (1963) and The Plantagents (1988). Her research involves diligently sifting through the archive material and rehearsal notes from the productions in order to demonstrate the nearly obsessive interest in bringing the dismembered body onto stage, making for two history cycles which 'proffer ... a blasonneur's disturbing negation of unity' (140).

Some of the strongest and most thought-provoking chapters in the volume address issues of gender power. Sara Morrison's contribution argues that Isabella in Measure for Measure and the Duchess in The Duchess of Malfi are not the subjects of male blazon. Rather, they use the language of pain, torture, martyrdom, and violence in their blazon-like descriptions of themselves. In Morrison's reading of Measure for Measure, Isabella uses self-blazon as a source of strength rather than subjugation. Through her assertion that 'Th'impression of keen whips I'd wear as rubies' (2.4.100) Isabella controls the gory imagery of flagellation, using it to make her case before Angelo that her inward chastity can become represented on her skin; taking control of the metaphorical battle that is being waged over her bodily agency.

The essays by Patricia Marchesi and Ariane M. Balizet remind the reader that male bodies can also be the subject of blazon: like the blazons of female bodies which are discussed elsewhere, male blazons can also be loaded with violence, humiliation, and de-humanization. Marchesi argues that Faustus's body, which is 'All torn asunder by the hand of death' (5.3.7), suffers the ultimate punishment of being reduced from its natural form to being a pile of theatrical props (92). Balizet writes about the description of the male cuckold's body as a form of blazon that turns the cuckolded characters in Arden of Faversham and A Woman Killed with Kindness into objects of ridicule, while also enhancing the imagery of their bodily disintegration. The metaphorical horns that are placed on the cuckolds' heads recall the horns that were used to torture Actaeon just before his body was dismembered by Diana's hounds.

Joseph M. Ortiz's essay refreshingly makes the case that in Shakespeare's history plays, blazon need not be a component of violent or sexual imagery at all. Ortiz argues that in Shakespeare's history plays, blazon is used in contexts that 'have little to do with erotic desire — or, for that matter, with any concern for physical beauty' (125), and instead demonstrates how blazon can be used to assert monarchical authority and legitimacy. While many of the 
authors in the volume contend that the dynamics of blazon rhetoric need not be constrained by the binary which divides a male subject from a female object, Sara D. Luttfring's essay turns the entire concept on its head, arguing that the pregnant female body in 'Tis Pity She's a Whore 'refuses to signify clearly' (165). Luttfring argues that there existed a tension between male medical writers who wished to understand the female body though anatomizing and observing it, and female midwives who understood the body through experience and access. This tension puts limits on male knowledge, allowing the pregnant woman's body to evade blazon and undermine the male desire to control the female body. When she becomes pregnant, Annabella's ability to control how much the men know about her body thwarts their attempts to control her. In her refusal to disclose the identity of the father to Soranzo, and by using Putana as a messenger to deliver the news to Giovanni, Annabella's body is not determined, examined, or anatomized by the male characters. The men must 'rely on women's words for complete information about the female body' (173) and are not able to subordinate her body to male authority until after she is silenced and dead.

Because the book's two main contributions to scholarly debate are to assert that staged blazons are 'at once reliant on, yet distinct from the lyric' (9) and to assert that anyone can be a blasonneur, rather than just male characters performing an act of erotic violence, the book ultimately turns attention to the role that the theatrical audience plays in the blazoning of the staged body. Putting blazon on stage rather than solely in lyric poetry makes the audience complicit because both the audience and the blasonneur are required to 'witness such figurative dismemberment, thereby confronting the cognitive dissonance that results from gazing at an intact yet punctured body' (9). In the final essay of this collection, Cora Fox discusses Cressida's role as an object of surveillance, both from the other characters and from the audience. 'As witnesses', Fox writes, 'the audience members are placed in positions that self-consciously distance us from a stable reading of Cressida's agency' (191). Elizabeth Williamson's essay on courtship practices in The Two Gentlemen of Verona also draws the reader's attention to the complicity of the theatrical audience. She argues that the play is the locus of a battleground that pits detractors of theatre against those who defend it. Julia's lively and evocative play-acting in her role as the page Sebastian teaches the audience to appreciate that performance is superior to the more stale conventions of courtly love exemplified in Proteus' courtship tactics. The audience's witnessing of the 


\section{Book Reviews}

power of blazon, therefore, becomes crucial to the play's success as a defence of theatre.

The contributors to this book provide a wide range of methodological approaches and a scope of primary sources that range from Phillip Sidney to Julie Taymor; but the book has, nonetheless, a cohesive thematic aim. The cohesion rests in its persistent statement that blazons can be performed and active, rather than textual and passive; blazons are witnessed rather than read, enacted rather than spoken. Ortiz's essay considers the Chorus's prologue in Henry $V$ which demands that the audience 'contribute[s] the full weight of its "imaginary forces" to help bridge the gap between wooden stage and French countryside' (127). Ortiz notes, however, that the language of the play repeatedly appropriates the language of printing, text, and books in order to encourage the audience not only to harness its imaginative power, but also to read the play as if it is an accurate, credible, history book (127-8). Ortiz's reading of Henry $V$ mirrors the argument about staging blazon that Morrison and Uman's book asserts: by taking a lyric form and staging it, the blazon encourages and privileges the audience's visual experience of theatre, while simultaneously drawing attention to itself as a poetic device. Blazons can indeed be staged, and when they are they resist definition, hovering evocatively in a space that is both poetry and performance.

\section{Notes}

1 Nancy J. Vickers, 'The Blazon of sweet beauty's best: Shakespeare's Lucrece', Patricia Parker and Geoffrey Hartman (eds), Shakespeare and the Question of Theory (New York, 1985), 95-115; 'Diana Described: Scattered Women and Scattered Rhymes', Critical Inquiry 8.2 (1981-2), 265-79. 